\title{
Papers
}

\section{Systematic review and meta-analysis of evidence for increasing numbers of drugs in antiretroviral combination therapy}

Rachel Jordan, Lisa Gold, Carole Cummins, Chris Hyde

\begin{abstract}
Objective To assess the evidence for the effectiveness of increasing numbers of drugs in antiretroviral combination therapy.

Design Systematic review, meta-analysis, and meta-regression of fully reported randomised controlled trials. All studies included compared quadruple versus triple therapy, triple versus double therapy, double versus monotherapy, or monotherapy versus placebo or no treatment.

Participants Patients with any stage of HIV infection who had not received antiretroviral therapy.

Main outcome measures Changes in disease progression or death (clinical outcomes); CD4 count and plasma viral load (surrogate markers).

Search strategy Six electronic databases, including Medline, Embase, and the Cochrane Library, searched up to February 2001.

Results 54 randomised controlled trials, most of good quality, with 66 comparison groups were included in the analysis. For both the clinical outcomes and surrogate markers, combinations with up to and including three (triple therapy) were progressively and significantly more effective. The odds ratio for disease progression or death for triple therapy compared with double therapy was 0.6 (95\% confidence interval 0.5 to 0.8 ). Heterogeneity in effect sizes was present in many outcomes but was largely related to the drugs used and trial quality.

Conclusions Evidence from randomised controlled trials supports the use of triple therapy. Research is needed on the effectiveness of quadruple therapies and the relative effectiveness of specific combinations of drugs.
\end{abstract}

\section{Introduction}

In 1987 zidovudine was introduced for the treatment of HIV infection. Since then there has been an escalation in the number of antiretroviral agents. Sequentially, treatment with two and then three drugs has become rapidly accepted. ${ }^{1-5}$ Treatment with four or more drugs has also been proposed. ${ }^{36}$

Influential clinical guidelines tend to be based on individual selected clinical trials, often published as conference abstracts. ${ }^{34}$ Early results from individual studies can be unrepresentative. ${ }^{8}$ Support for the clinical benefit of increasing drug combinations comes from well conducted cohort studies, ${ }^{9-14}$ but the length of follow up is still too short to assess the long term clinical benefit of triple therapy.

Systematic reviews have examined questions about the effectiveness of specific drugs and combinations or have included trials with a mixture of patients who have and have not received drug treatment. ${ }^{15-20}$ We carried out a systematic review on the effectiveness of increasing numbers of drugs used in combination. To reduce the potential for confounding by established drug resistance we looked only at those patients who had not previously received antiretroviral therapy.

\section{Methods}

\section{Search strategy and inclusion criteria}

This review was conducted to the suggested QUOROM guidelines standards. ${ }^{21}$ We looked for randomised controlled trials of antiretroviral therapy in HIV patients (up to the end of February 2001) in Medline, the Cochrane Library, Embase, CINAHL, PsycLIT, Healthstar, appropriate internet sites such as AIDSTRIALS, and citation lists. We also contacted pharmaceutical companies. There was no language restriction. We included studies only if they included patients who were HIV positive (any stage) and were aged $\geqslant 12$ years with less than six months' previous antiretroviral therapy or if less than $30 \%$ of patients had previous therapy or if patients who had never had therapy were reported separately. The accepted interventions were any licensed (United Kingdom or United States) antiretroviral drug (or combination) compared with any other antiretroviral drug or placebo or no treatment. We excluded studies if they lasted less than 12 weeks.

We assessed studies for quality using a standard checklist. ${ }^{22}$ Data were extracted by two independent reviewers. We included and listed in the review those trials that did not provide any useful measure of variance or had no events, but the data from these trials could not be used in the analyses.

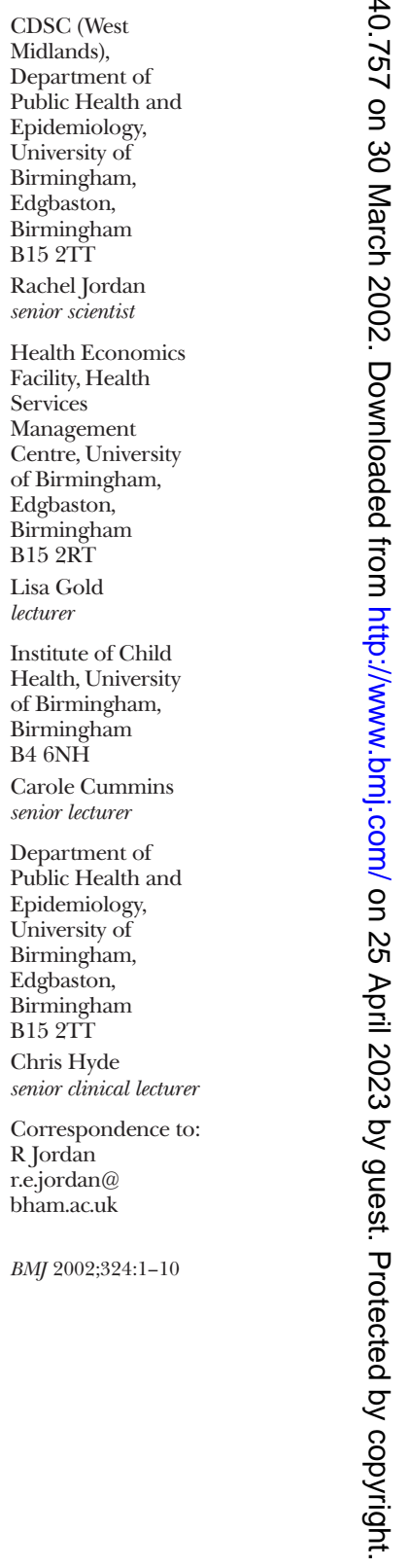


Antiretroviral drug comparisons included in analyses of clinical outcomes and surrogate markers

\begin{tabular}{|c|c|c|}
\hline Trials & $\begin{array}{c}\text { No of } \\
\text { comparisons }\end{array}$ & Comparison \\
\hline \multicolumn{3}{|l|}{ Monotherapy $v$ placebo or no treatment } \\
\hline $\begin{array}{l}\text { Koot, },{ }^{41} \text { ACTG } 116 A,{ }^{46} \text { Kinloch-de-Loes, }{ }^{45} \text { Evers },{ }^{51} \text { ISS } 902,{ }^{49} \text { Concorde, }{ }^{42} \text { DATRI } \\
\text { 002, }{ }^{50} \text { VACS } 298,{ }^{37}{ }^{38} \text { ACTG 016, }{ }^{34} \text { ACTG 019, }{ }^{32}{ }^{33} \text { EACGS, }{ }^{39} \text { EACG 017, }{ }^{44} \\
\text { Fischl, }{ }^{26} \text { Mannucci, }{ }^{43} \text { NHF-ACTG 036 }{ }^{36}\end{array}$ & 18 & Zidovudine $v$ placebo or no treatment \\
\hline \multicolumn{3}{|l|}{ Double therapy $v$ monotherapy } \\
\hline \multicolumn{3}{|l|}{ Two nucleosides: } \\
\hline NUCB $3001(2),{ }^{60}$ NUCA $3001(2)^{55}$ & 4 & Zidovudine + lamivudine $v$ zidovudine \\
\hline NUCA $3001(2)^{55}$ & 2 & Zidovudine + lamivudine $v$ lamivudine \\
\hline ACTG $306^{66}$ & 1 & Zidovudine + lamivudine $v$ stavudine \\
\hline Protocol $34,225-02,{ }^{61}$ DELTA-1, ${ }^{58} 59$ ACTG $175^{57}$ & 3 & Zidovudine + didnaosine $v$ zidovudine \\
\hline ACTG $175^{57}$ & 1 & Zidovudine + didanosine $v$ didanosine \\
\hline Protocol 34, 225-02, ${ }^{61}$ DELTA-1, ${ }^{58}{ }^{59} \quad$ ACTG $175,{ }^{57}$ M50003, ${ }^{62}$ Kaulen $^{52}$ & 5 & Zidovudine + zalcitabine $v$ zidovudine \\
\hline ACTG $175^{57}$ & 1 & Zidovudine + zalcitabine $v$ didanosine \\
\hline ACTG $306^{66}$ & 1 & Stavudine + lamivudine $v$ stavudine \\
\hline ACTG $306^{66}$ & 1 & Didanosine + lamivudine $v$ didanosine \\
\hline QUATTRO $^{77}$ & 1 & Zidovudine + lamivudine $v$ ZDV-Lam-Lov-Zalc* \\
\hline Yarchoan $^{53}$ & 1 & Zidovudine + didanosine $v$ ZDV-did ${ }^{*}$ \\
\hline ACTG $306^{66}$ & 1 & Zidovudine + lamivudine $v$ didanosine \\
\hline HIV-NAT $002^{80}$ & 1 & Stavudine + didanosine $v$ didanosine \\
\hline \multicolumn{3}{|l|}{ Nucleoside + protease inhibitor: } \\
\hline Vella ${ }^{56}$ & 1 & Zidovudine + saquinavir $v$ zidovudine \\
\hline Vella $^{56}$ & 1 & Zidovudine + saquinavir $v$ saquinavir \\
\hline Lewi $^{79}$ & 1 & Zidovudine + indinavir $v$ zidovudine \\
\hline Lewi $^{79}$ & 1 & Zidovudine + indinavir $v$ indinavir \\
\hline \multicolumn{3}{|l|}{ Triple therapy $v$ double therapy } \\
\hline \multicolumn{3}{|l|}{ Two nucleosides + non-nucleoside: } \\
\hline INCAS $^{68}$ Floridia $^{69}$ & 2 & Zidovudine + didanosine + nevirapine $v$ zidovudine + didanosine \\
\hline INCAS $^{68}$ & 1 & Zidovudine + didanosine + nevirapine $v$ zidovudine + nevirapine \\
\hline ACTG $261^{70}$ & 1 & Zidovudine + didanosine + delavirdine $v$ zidovudine + didanosine \\
\hline ACTG $261^{70}$ & 1 & Zidovudine + didanosine + delavirdine $v$ zidovudine + delavirdine \\
\hline ACTG $261^{70}$ & 1 & Zidovudine + didanosine + delavirdine $v$ didanosine + delavirdine \\
\hline Study $006^{73}$ & 1 & Zidovudine + lamivudine + efavirenz $v$ efavirenz + indinavir \\
\hline Protocol 0021 part $1{ }^{85}$ & 1 & Zidovudine + lamivudine + delavirdine $v$ zidovudine + lamivudine \\
\hline Protocol 0021 part $1{ }^{85}$ & 1 & Zidovudine + lamivudine + delavirdine $v$ zidovudine + delavirdine \\
\hline AVANTI- $1^{72}$ & 1 & Zidovudine + lamivudine + loviride $v$ zidovudine + lamivudine \\
\hline \multicolumn{3}{|l|}{ Two nucleosides + protease inhibitor: } \\
\hline EARTH-1 ${ }^{75}$ & 1 & Stavudine + lamivudine + ritonavir $v$ zidovudine + didanosine \\
\hline EARTH-1 ${ }^{75}$ & 1 & Stavudine + lamivudine + ritonavir $v$ zidovudine + zalcitabine \\
\hline EARTH-1 ${ }^{75}$ & 1 & Stavudine + lamivudine + ritonavir $v$ stavudine + didanosine \\
\hline PROAB $3001,{ }^{81}$ PROAB $2002^{76}$ & 2 & Zidovudine + lamivudine + amprenavir $v$ zidovudine + lamivudine \\
\hline Study $006^{73}$ & 1 & Zidovudine + lamivudine + indinavir $v$ efavirenz + indinavir \\
\hline Opravil $^{82}$ & 1 & Zidovudine + lamivudine + ritonavir $v$ zidovudine + lamivudine \\
\hline AVANTI- $2^{84}$ & 1 & Zidovudine + lamivudine + indinavir $v$ zidovudine + lamivudine \\
\hline PISCES $^{86}$ & 1 & Zidovudine + zalcitabine + saquinavir $v$ zalcitabine + saquinavir \\
\hline PISCES $^{86}$ & 1 & Zidovudine + zalcitabine + saquinavir $v$ zidovudine + zalcitabine \\
\hline AVANTI- $3^{83}$ & 1 & Zidovudine + lamivudine + nelfinavir $v$ zidovudine + lamivudine \\
\hline
\end{tabular}

*Alternating therapy: ZDV=zidovudine; Lam=lamivudine; Lov=loviride; Zalc=zalcitabine; did=didanosine.

\section{Data analysis}

Data were collected on all relevant outcomes, with disease progression and deaths as clinical outcomes and CD4 count and viral load as surrogate markers.

To take account of the large dropout rates but to maximise the length of time in the trial, we measured CD4 count and viral load at the longest time point when at least half of the total number of patients in each arm remained.

\section{Meta-analysis}

For continuous outcomes (CD4 count and viral load change) we calculated the treatment effect for individual trials as the treatment effect (that is, mean change) minus the control effect. We calculated the standard error of the weighted mean difference by adding the variances of the change in outcome in both groups and taking the square root. For triple therapy we also present data on viral load as the proportion of patients in whom concentrations of plasma virus became too low to be detected $(<50$ copies per $\mathrm{ml}$ ). We pooled data using the inverse variance method of weighting (for continuous outcomes) and the fixed effects Peto method for event rates. ${ }^{23}$ Significance was set at $\mathrm{P}<0.05$. We assessed statistical heterogeneity using the $\chi^{2}$ test. $^{24}{ }^{25}$ When there were several arms within a trial that allowed more than one comparison per arm we weighted the number of events and the number of participants so that each participant was used only once.

We explored heterogeneity using sensitivity and subgroup analyses and fixed effects weighted regression techniques (Stata 5.0 software), with the covariates of trial duration, baseline CD4 count/viral load, dropout rates, drug dose, specific drug or drugs 

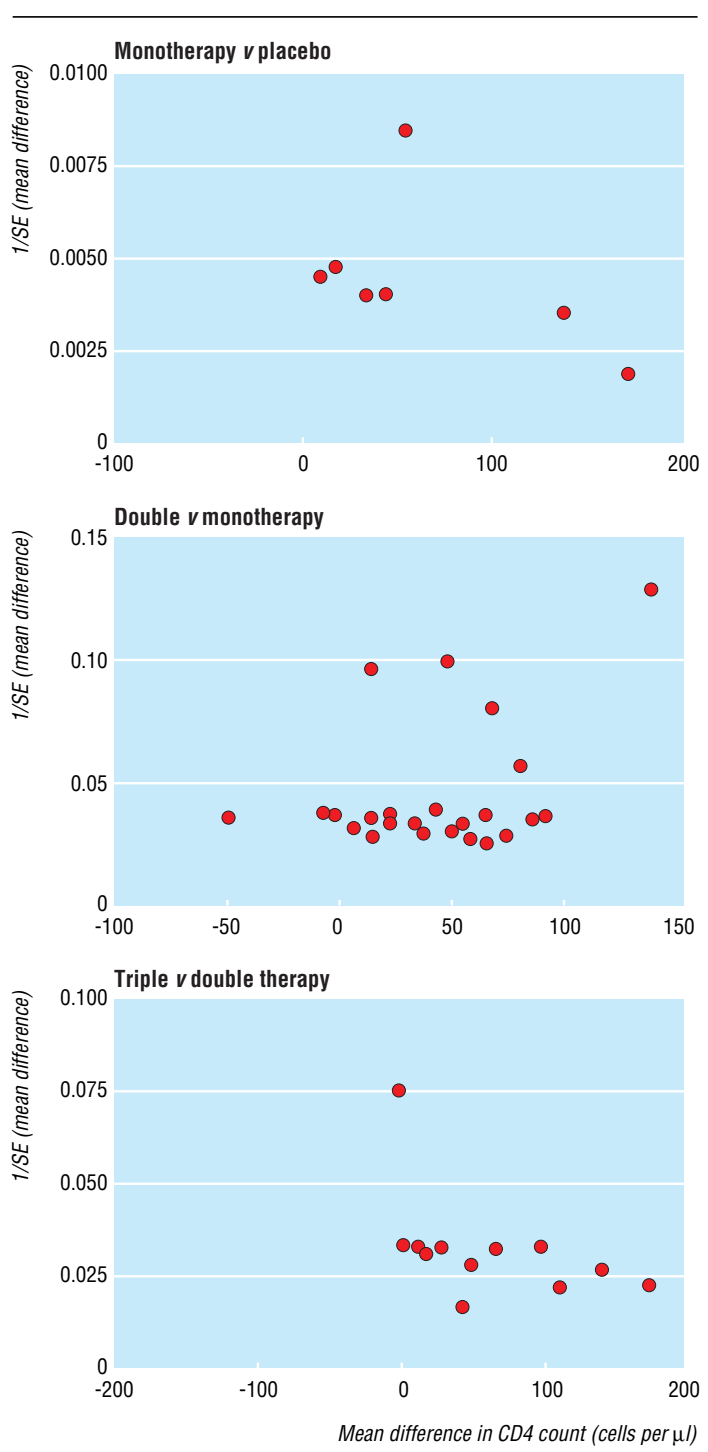

Fig 1 Funnel plots of CD4 count results for monotherapy versus placebo, double therapy versus monotherapy, and triple therapy versus double therapy

(presence of protease inhibitors or zidovudine), change in CD4/viral load (mean/median/change/end point),

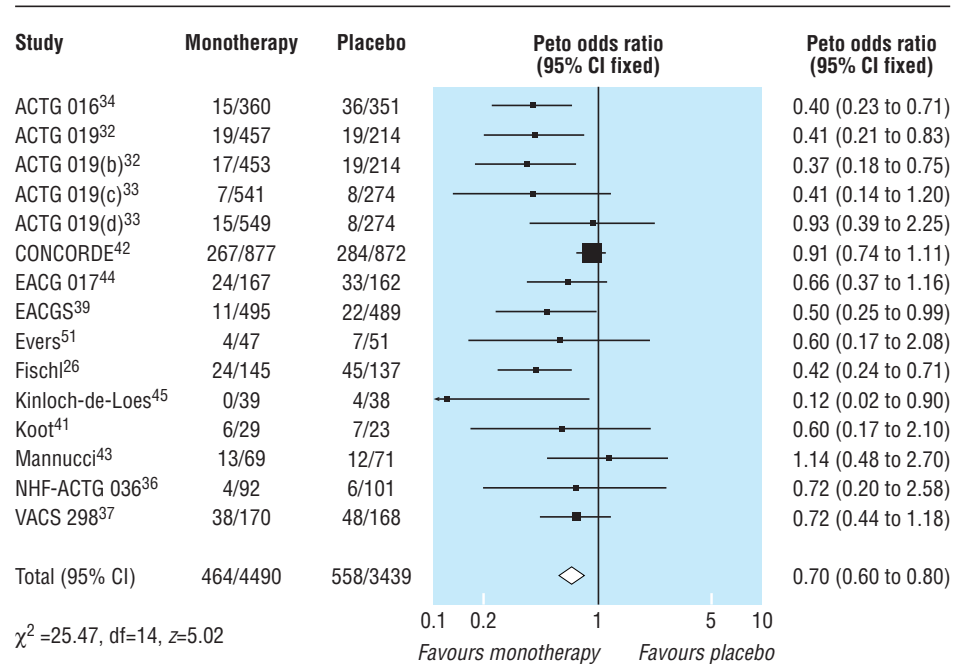

Fig 2 Effect of zidovudine monotherapy versus placebo on disease progression or death. Figures are number of events/number of participants

sensitivity of the viral load assay, and blinding and concealment of allocation.

We assessed publication bias visually using a funnel plot and statistically using Egger's and Begg's tests (Stata 5.0).

\section{Results}

Quantity, quality, and characteristics of trials

Out of over 2000 search "hits" we retrieved 700 papers and finally included 90 , which referred to 54 different trials ${ }^{26-86}$ and 20404 patients. The trials were generally of good quality and randomised. Concealment of allocation was confirmed in a third, most were double blind, and participants in each arm were comparable within trials. Over $80 \%$ of the participants were men, with an average age ranging between 27 and 40 years. More patients were asymptomatic than at any other clinical stage, mean baseline CD4 counts ranged from 83-660 cells per $\mu \mathrm{l}$, and mean viral load ranged from 2.35 to $7.35 \mathrm{log}$ copies per $\mathrm{ml}$. The length of the trials varied from 12 weeks to 4.8 years, although follow up was not always clearly reported.

The table lists the comparisons available for the analyses. Zidovudine was the only monotherapy

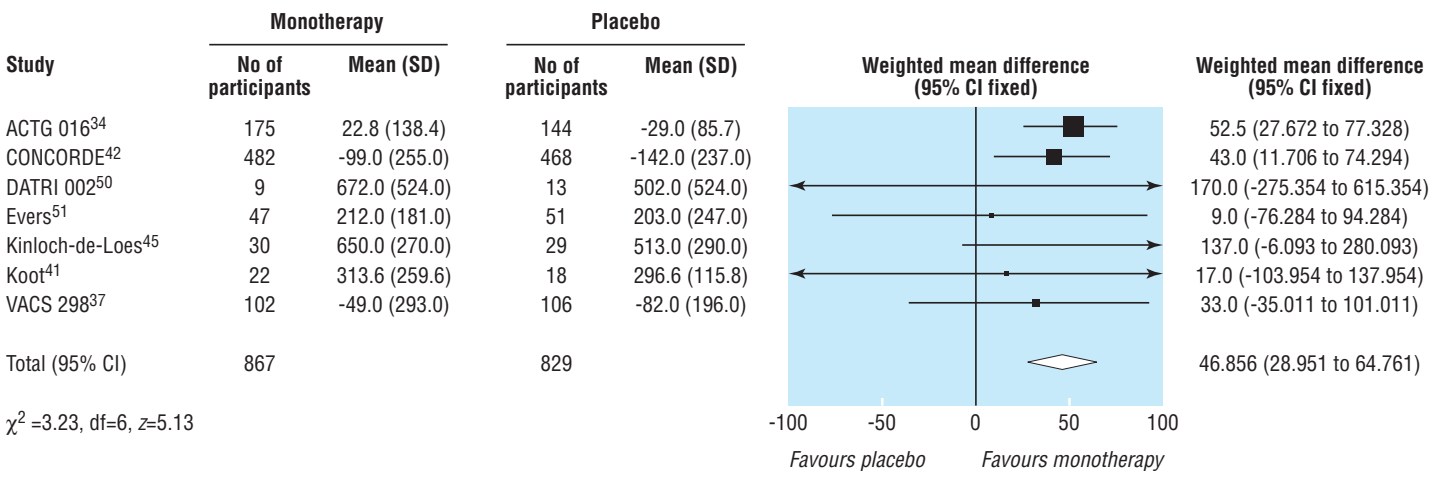

Fig 3 Effect of zidovudine monotherapy versus placebo on change in mean (SD) CD4 count (cells per $\mu$ l) 


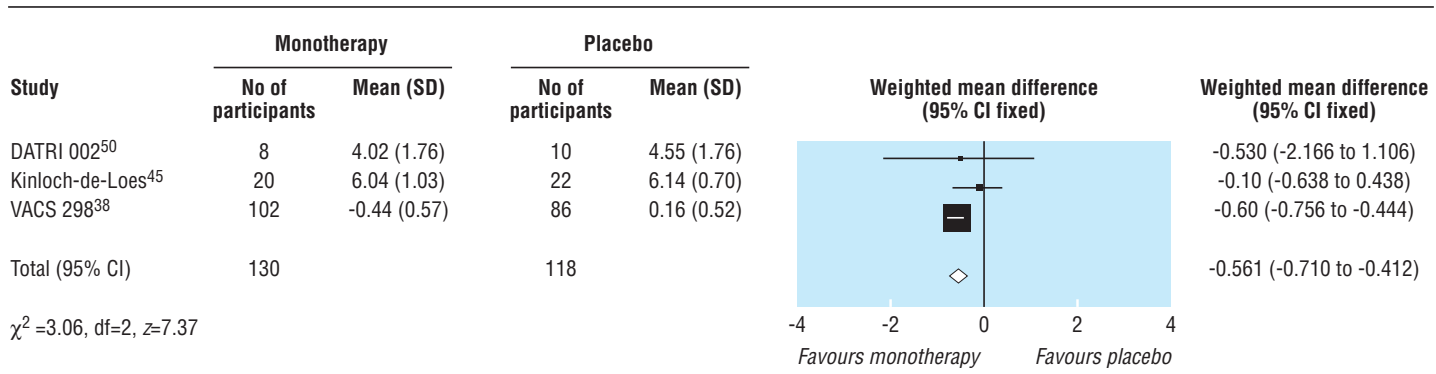

Fig 4 Effect of zidovudine monotherapy versus placebo on change in mean (SD) viral load (log copies per ml)

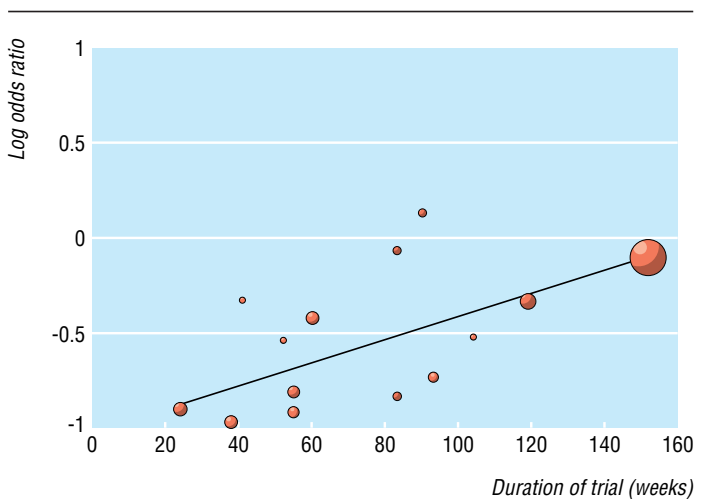

Fig 5 Duration of trial and odds of disease progression or death with zidovudine monotherapy versus placebo

compared with placebo or no treatment. The most common double therapies were two nucleosides, most which were compared against zidovudine or didanosine monotherapy. Triple therapies were mainly based on the currently advised pattern of two nucleosides (usually zidovudine plus didanosine or lamivudine) with the addition of a protease inhibitor or a non-nucleoside. One trial compared quadruple therapy (two nucleosides plus ritonavir plus saquinavir at lower doses given to boost each other rather than as

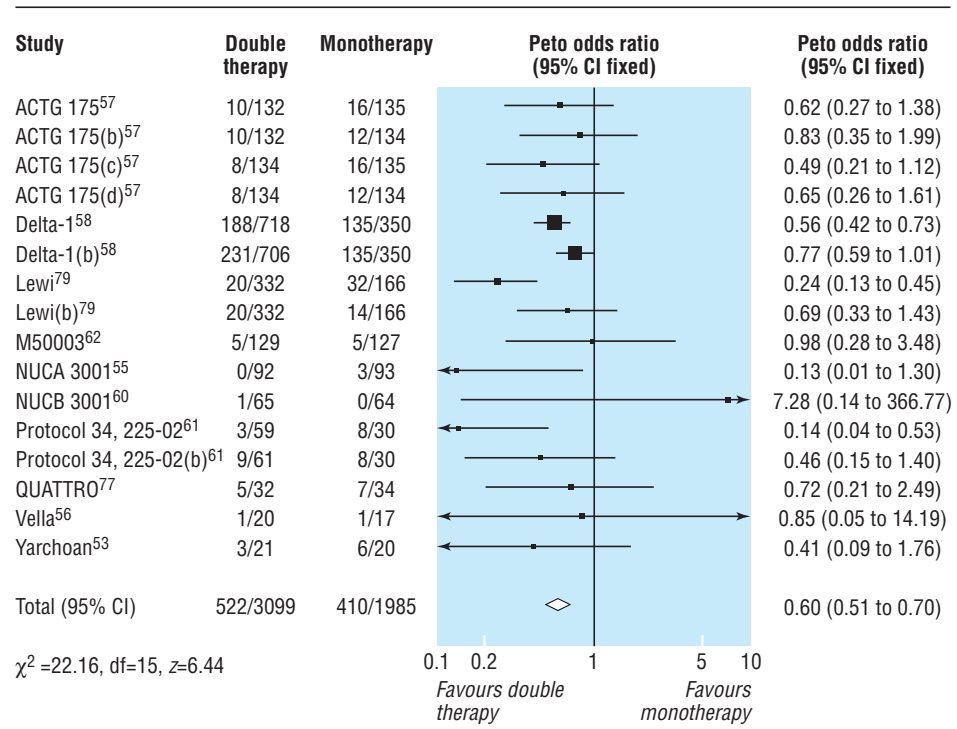

Fig 6 Effect of double therapy versus monotherapy on disease progression or death. Figures are number of events/number of participants a true full dose quadruple combination) and therefore was not incorporated into the analyses. ${ }^{78}$ Other unusual interventions (such as cyclical or intermittent therapies) were not included in the analyses. We classified immediate versus deferred zidovudine as zidovudine versus placebo.

\section{Potential publication bias}

We found no consistent visual or statistical evidence of publication bias (that is, the tendency that small studies are more likely to be published if they have significant positive results) except for CD4 count for triple versus double therapy, where there was a clear lack of small studies with negative results (fig1). The limitations of the techniques, particularly when there are few trials and there is heterogeneity present, mean we cannot exclude publication bias.

\section{Main outcomes}

Monotherapy compared with placebo

Fifteen trials compared monotherapy with placebo. $^{26}$ 32-34 36-39 41-45 50 51 Compared with placebo, zidovudine significantly reduced disease progression or death (odds ratio $0.7,95 \%$ confidence interval 0.6 to 0.8 ), although there was substantial heterogeneity (fig 2). Zidovudine also resulted in an improvement in CD4 count of 47 cells per $\mu \mathrm{l}$ (29 to 65) with no important heterogeneity (fig 3 ) and a viral load reduction of 0.56 log copies per $\mathrm{ml}(0.71$ to 0.41$)$ with some unexplained heterogeneity (fig 4). The heterogeneity present in the clinical outcome data (range of odds ratio 0.1-1.1, fig 2) was in part explained by the variable duration of the trials: as the trials increased in length zidovudine had a smaller relative effect. At 152 weeks (about three years), as in the Concorde trial, ${ }^{42}$ the beneficial effect of zidovudine was virtually eliminated (fig 5).

\section{Double therapy compared with monotherapy}

We found 14 trials that compared double therapy with monotherapy (figs 6-8). ${ }^{52} 5355-6266777980$ Double therapy resulted in significantly better clinical outcomes than monotherapy did (fig 6) (odds ratio for disease progression/death was $0.6,0.5$ to 0.7 ). There was some heterogeneity, but this seemed to be largely accounted for by one large trial of protease inhibitors. ${ }^{79}$ Sensitivity analysis in which we excluded this trial did not alter the effect size or confidence intervals. In contrast with the results for monotherapy the trial duration did not explain the heterogeneity, despite ranging from six months to three years.

Results for surrogate markers were significantly better with double therapy than with monotherapy (figs 7 and 8). Subgroup analyses showed that 


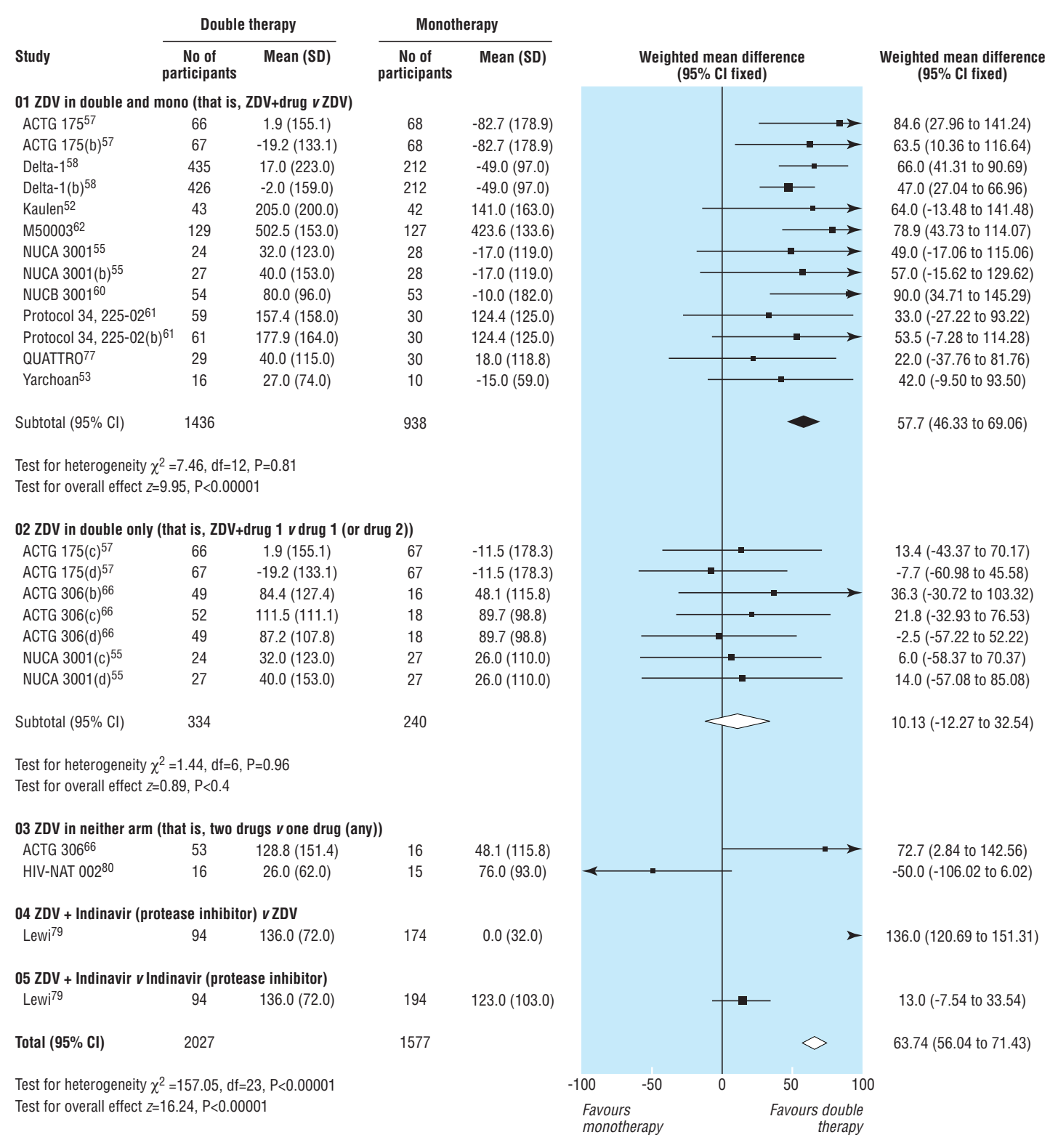

Fig 7 Effect of double therapy versus monotherapy on change in mean (SD) CD4 count (cells per $\mu$ l)

heterogeneity in the CD4 counts was wholly accounted for by the presence of zidovudine or protease inhibitors (fig 7), which suggests that combinations that contain protease inhibitors may be more effective than other double therapies and that monotherapy with zidovudine is less effective compared with other monotherapies. Heterogeneity was present in the analysis of viral load, but exploratory analyses were not informative.

\section{Triple therapy compared with double therapy}

We found 12 trials of triple therapy compared with double therapy (fig 9-12). ${ }^{68-70} 72737581-86$ Triple therapy significantly improved clinical outcomes compared with double therapy (odds ratio for disease progression/death was $0.6,0.5$ to 0.8 ) (fig 9), although most trials had few events. Only one large trial lasted over a year, and this contributed most events. ${ }^{86}$ The heterogeneity was attributable to one open label study with few events. ${ }^{73}$ In a sensitivity analysis that excluded this study we found no change in the estimates of effect size. The results for the surrogate markers (CD4 and viral load) were consistent with those for the clinical outcomes, showing that triple therapy was significantly better than double therapy, though there was substantial heterogeneity in all analyses. Regression analyses of both the CD4 count and the change in viral load indicated that possible causes of this heterogeneity were issues of quality (concealment of allocation and non-blinding) and types of drugs used.

\section{Other outcomes}

Twenty six trials gave information on drug related withdrawals. $30333436373942-4551555860616368697273757681828486$

Dropout rates were higher with monotherapy than with placebo but no different between double therapy and monotherapy. The results of triple compared with dou- 


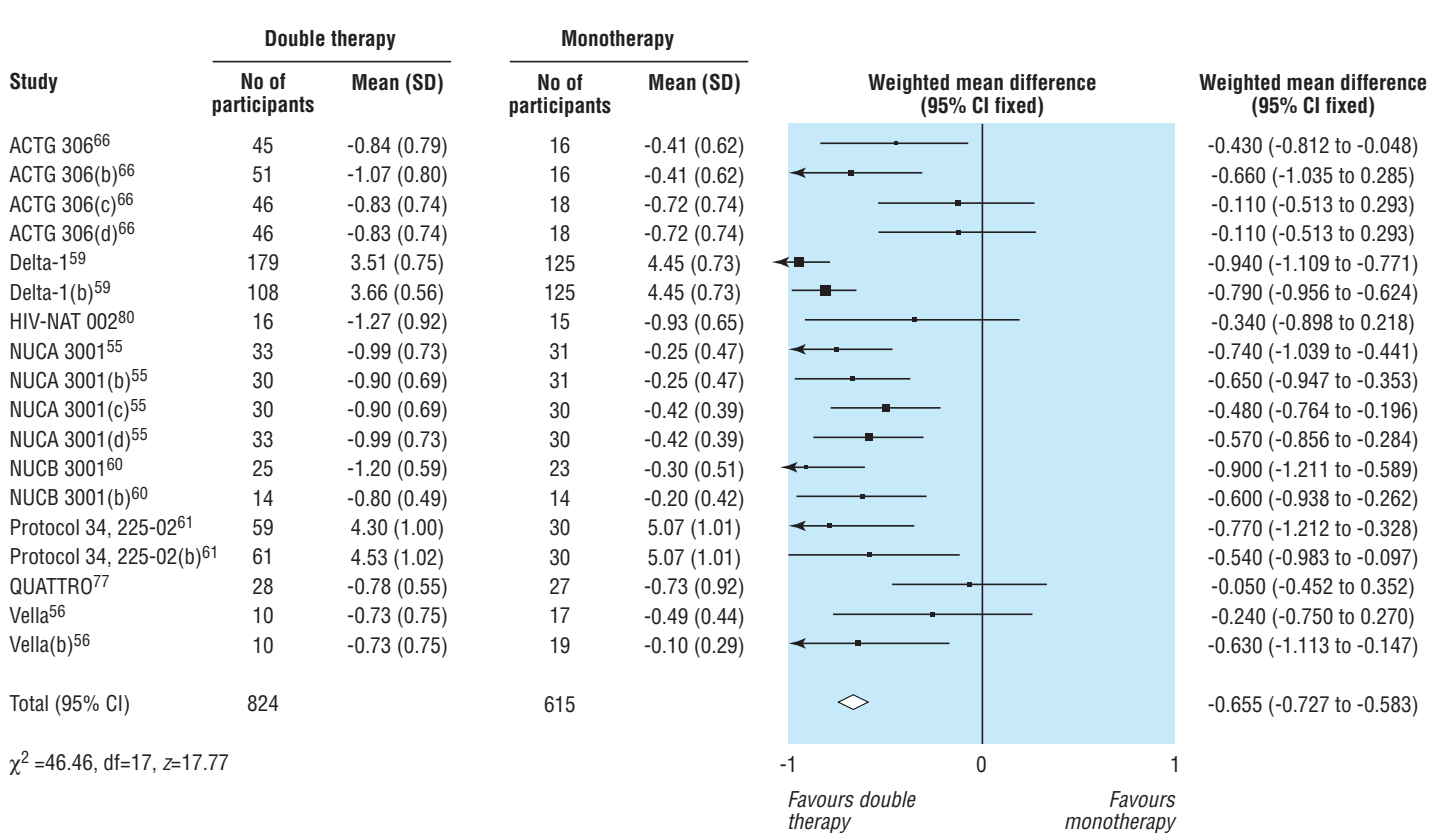

Fig 8 Effect of double therapy versus monotherapy on change in mean (SD) viral load (log copies per ml)

ble therapy were heterogeneous. Subgroup classification of trials according to presence of protease inhibitors suggested that there was no significant difference in dropout rates between triple therapy without a protease inhibitor and double therapy without a protease inhibitor. Trials of therapies that contained a protease inhibitor in the triple but not the double arm had significantly higher withdrawals. The exception to this was the PISCES trial, ${ }^{86}$ the only trial that included saquinavir in the triple arm (fig 13). Only four trials gave useful information regarding quality of life related to health, ${ }^{27-29} 4771$ and they had inconsistent results.

\section{Discussion}

\section{Principal findings}

This systematic review of combination therapy for people with HIV showed a consistently and significantly greater benefit for increasing numbers of drugs up to, and including, triple therapy for clinical outcomes and surrogate markers. Marked variation in

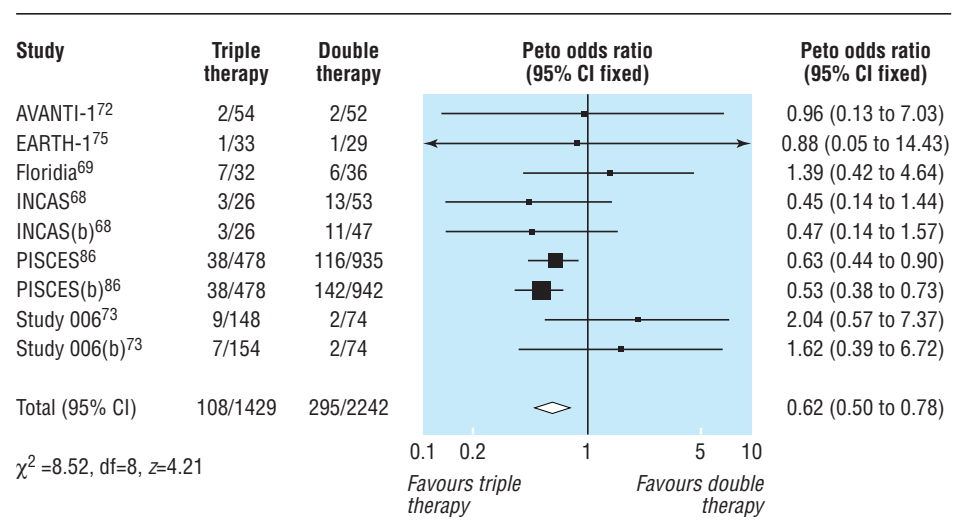

Fig 9 Effect of triple therapy versus double therapy on disease progression or death. Figures are number of events/number of participants the results for many outcomes was greater than could be accounted for by chance alone. When we investigated the effects of potential confounders on the results we found that the heterogeneity for monotherapy was largely explained by decreasing effectiveness over time, which is consistent with the development of drug resistance. For double and triple therapy, the heterogeneity was mainly accounted for by the drugs tested (possible greater effectiveness of protease inhibitors and weaker effect of zidovudine) and issues of quality (blinding and concealment of allocation) for particular trials but was not always consistent between different surrogate and clinical outcomes. We found no published trials on the effectiveness of true full dose quadruple therapy.

\section{Strengths and weaknesses}

HIV patients who have never received antiretroviral drugs comprise only a part of clinical practice, but establishment of the effectiveness of such treatment in these patients is fundamental to understanding the overall relative benefit of the drugs, and subsequent treatment decisions are contingent on the initial choice. Though choice of this study population reduced confounding, other potential causes of clinical heterogeneity were reflected in the results. Exploration of heterogeneity with regression techniques suggested that different drugs might explain some of the variation. This conclusion must be tempered with caution as post hoc analyses are purely exploratory and the techniques used are limited, with small numbers of observations. Data on individual patients would allow better exploration of the effect of patient characteristics, although such techniques are usually too expensive and time consuming. ${ }^{87}$ In addition, some of these findings are based on surrogate end points and should be confirmed by clinical end points, which are less well reported in published trials. Data on adverse events are difficult to interpret in the context of HIV 


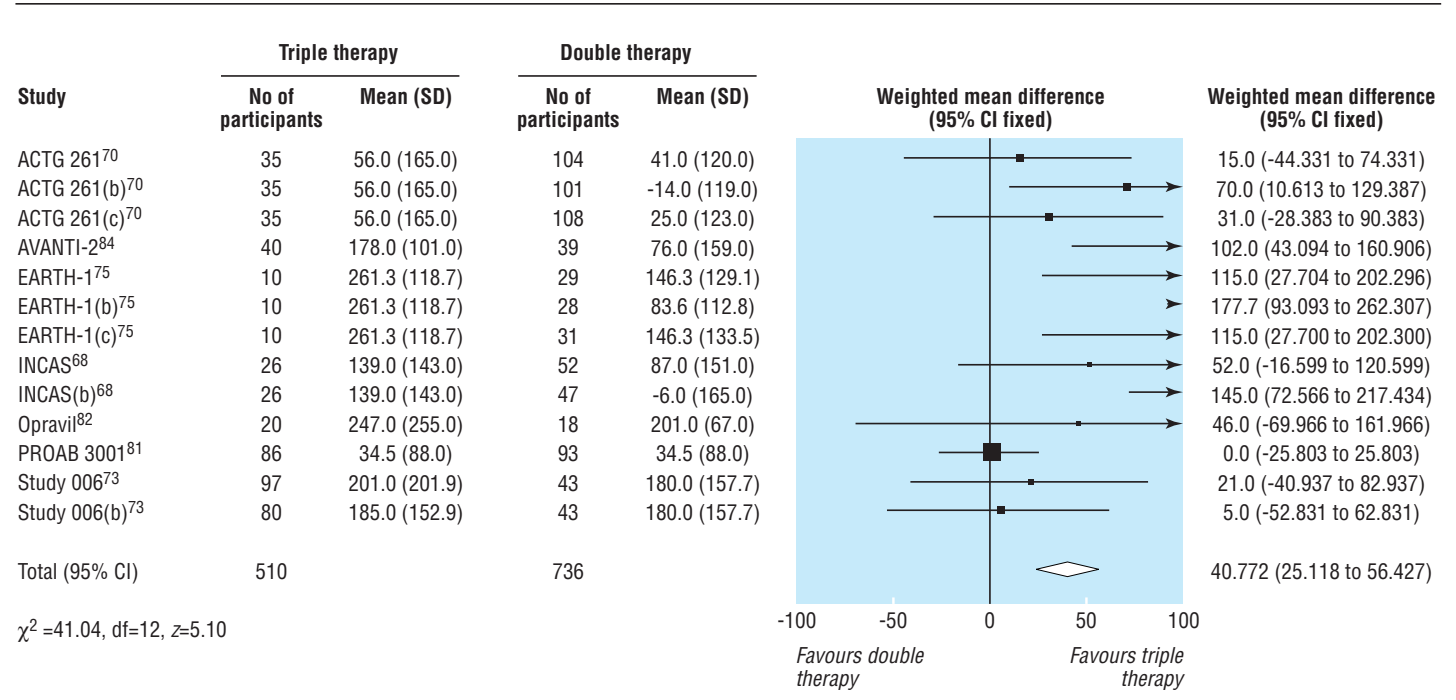

Fig 10 Effect of triple therapy versus double therapy on change in mean (SD) CD4 count (cells per $\mu$ l)

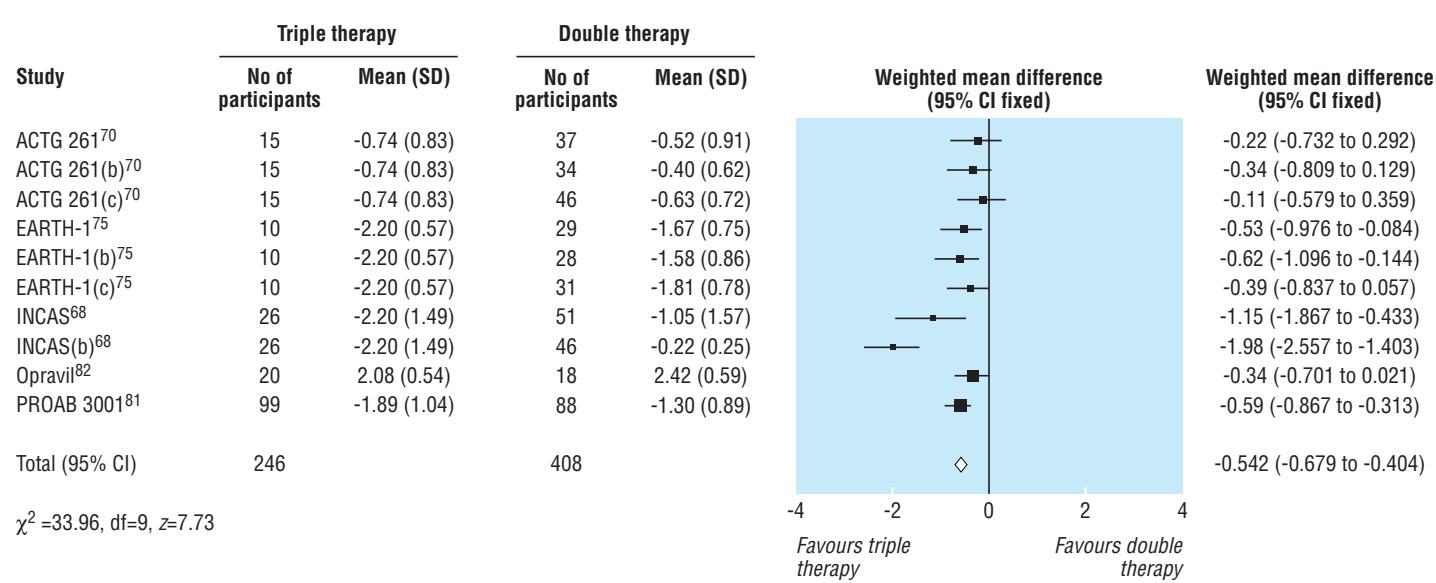

Fig 11 Effect of triple therapy versus double therapy on change in mean (SD) viral load (log copies per ml)

trials in which patient behaviour may differ from clinical practice, and a full evaluation of adverse events should include postmarketing surveillance. Despite a rigorous search for trials, the possibility of publication bias cannot be completely excluded.

Implications and future research

This systematic review provides new evidence that the escalation of combinations of antiretroviral drugs up to triple therapy is an effective strategy. Our results for the relative effectiveness of monotherapy versus placebo and double therapy versus monotherapy are consistent with the results of smaller meta-analyses. ${ }^{19}{ }^{20}$ Also, the overall findings are supported by the results of cohort studies. $^{9-14}$ However, there is no fully published evidence on the effectiveness of quadruple or higher combinations.

Exploratory analyses of the variation in results showed that differences resulted from the specific drugs used. Both effectiveness and cost considerations indicate that future work to clarify which triple combination is the most effective is as important as investigating the effectiveness of quadruple or higher combinations. As the number of drugs increases, qual- ity of life and safety assume relatively greater importance but are currently inadequately reported.

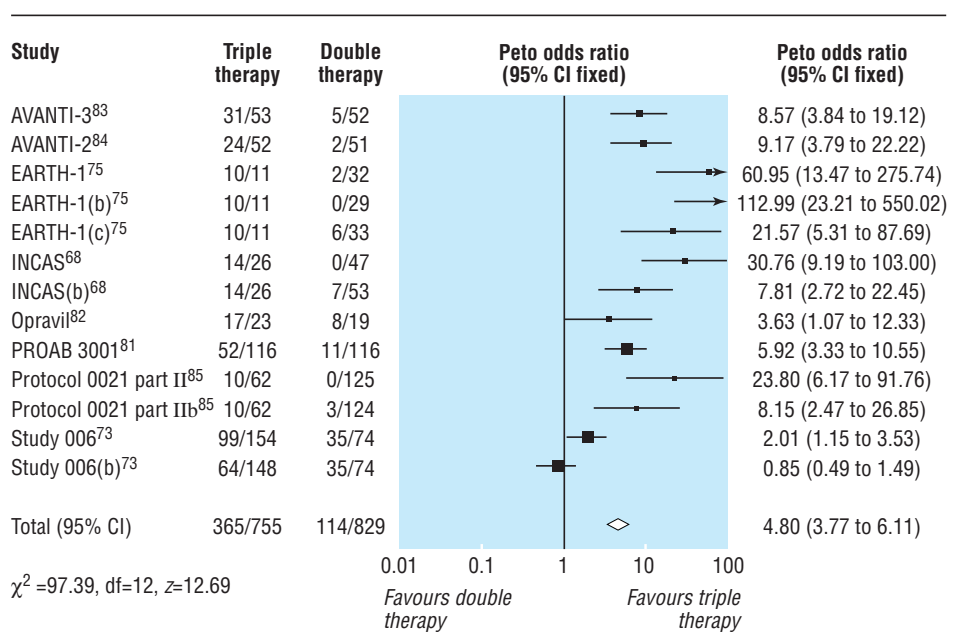

Fig 12 Effect of triple therapy versus double therapy on proportion of participants reaching undetectable viral load. Figures are number of events/number of participants 


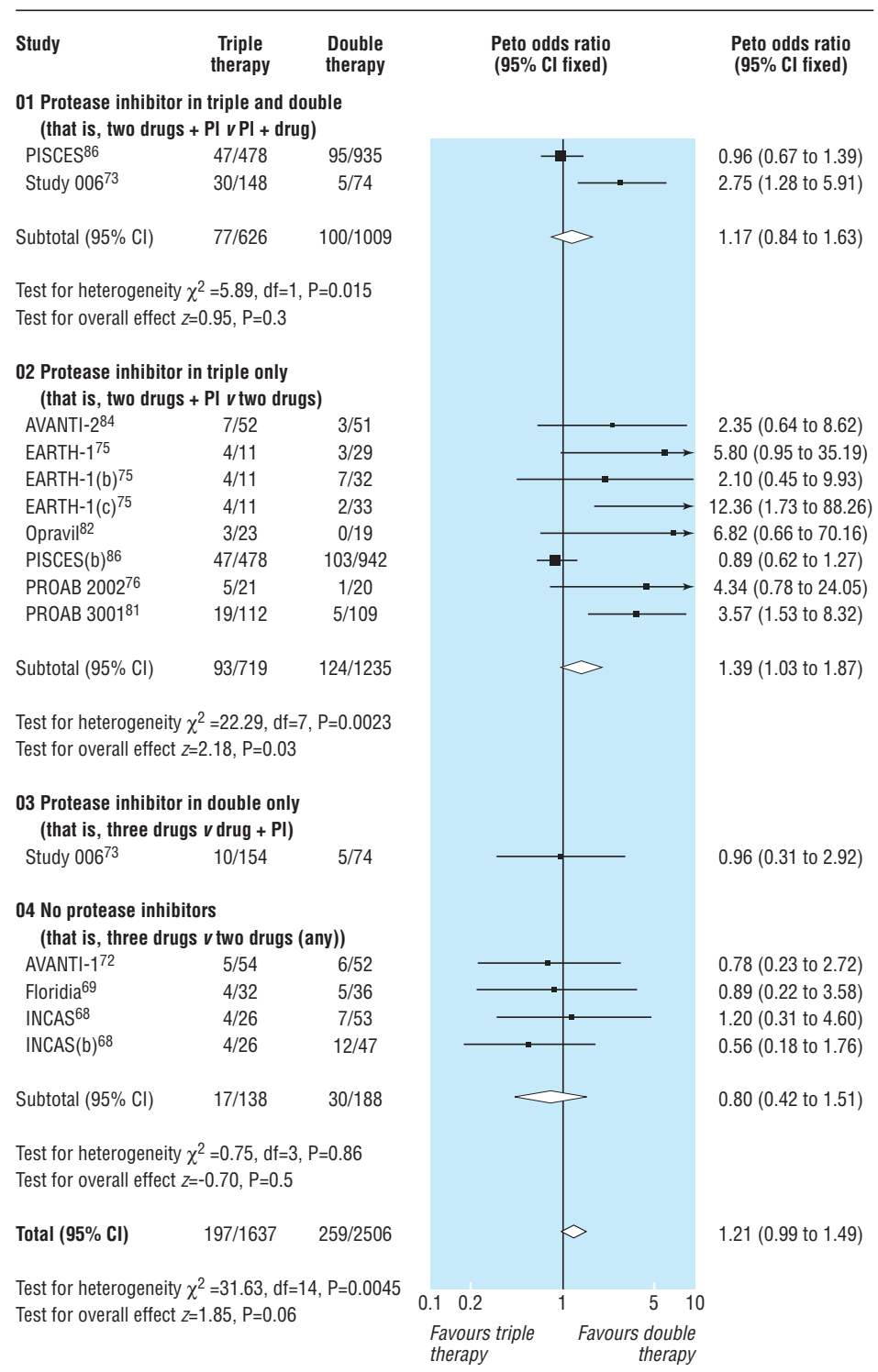

Fig 13 Triple therapy versus double therapy and withdrawals due to adverse events related to drug treatment

\section{What is already known on this topic}

Triple combination antiretroviral therapy is accepted by clinicians and patients as the usual treatment for HIV and has evolved through an incremental strategy in the numbers of drugs combined

Guidance on treatment, however, has predominantly been based on early reports of research

There are no published analyses that assess the effectiveness of the increasing numbers of drugs used in combination

\section{What this study adds}

The results of this systematic review support the use of triple therapy but there is inadequate evidence for quadruple or higher combinations

Heterogeneity in the effect estimates seems to result from variable effectiveness of different drug combinations, trial duration, and problems with study quality

\section{Competing interests: None declared.}

1 Carpenter CCJ, Fischl MA, Hammer SM, Hirsch MS, Jacobsen DM, Katzenstein DA, et al. Antiretroviral therapy for HIV infection in 1996 Recommendations of an international panel. International AIDS Society-USA. JAMA 1996;276:146-54.

2 BHIVA Guidelines Coordinating Committee. British HIV Association guidelines for antiretroviral treatment of HIV seropositive individuals. Lancet 1997;349:1086-92.

3 BHIVA Writing Committee on behalf of the BHIVA Executive Committee. British HIV Association (BHIVA) guidelines for the treatment of HIV-infected adults with antiretroviral therapy, 1999 www.aidsmap.com/about/bhiva/bhivagd1299.asp (accessed Dec 1999).

4 Carpenter CCJ, Cooper DA, Fischl MA, Gatell JM, Gazzard BG, Hammer SM, et al. Antiretroviral therapy in adults. Updated recommendations of the International AIDS Society-USA panel. JAMA 2000;283:381-90.

5 BHIVA Writing Committee on behalf of the BHIVA Executive Committee. British HIV Association (BHIVA) guidelines for the treatment of HIV-infected adults with antiretroviral therapy, 2001. www.bhiva.org/guidelines.htm (accessed Jan 2002).

6 Gallant JE. Antiretroviral strategies and controversies. Medscape HIV/AIDS 1999;5(suppl). www.medscape.com/viewarticle/412666 (accessed Jan 2000).

7 Clinical Evidence. A compendium of the best available evidence for effective health care. London: BMJ Publishing Group, 2001 (issue 6).

Better evidence is required. The exploratory analyses of heterogeneity indicate that the design of future trials must be more rigorous and less variable (for example, in trial duration, test drugs, comparators, and clinical stage at entry) and should not rely on surrogate outcomes alone. The research community must respond. There are still important questions to be answered about the effectiveness of existing agents. This may require publicly funded trials which should be carried out within a clear well supported collaborative framework.

We thank Jeremy Hawker, Paul Aveyard, Matthias Egger, Sarah Walker, and Abdel Babiker for their valuable comments.

Contributors: RJ was the main reviewer; conducted the search, data extraction, evaluation, and analyses; and wrote the paper. LG performed the double data extraction, advised on direction, and commented on the text. CC advised on and performed the statistics and cowrote the text. $\mathrm{CH}$ advised on direction and interpretation of the analyses, made substantial comments on the text, and is guarantor. Levy.

Funding: UK West Midlands NHS Regional Public Health

Antman EM, Lau J, Kupelnick B, Mosteller F, Chalmers TC. A comparison of results of meta-analyses of randomized controlled trials and recommendations of clinical experts. Treatment for myocardial infarction. JAMA 1992;268:240-8.

9 Ledergerber B, Egger M, Opravil M, Telenti A, Hirschel B, Battegay M, et al. Clinical progression and virological failure on highly active antiretroviral therapy in HIV-1 patients: a prospective cohort study. Lancet 1999;353:863-8.

10 Mocroft A, Katlama C, Johnson AM, Pradier C, Antunes F, Mulcahy F, et al. AIDS across Europe, 1994-98: the EuroSIDA study. Lancet 2000;356:291-6.

11 Egger M, Hirschel B, Francioli P, Sudre P, Wirz M, Flepp M, et al. Impact of new antiretroviral combination therapies in HIV infected patients in Switzerland: prospective multicentre study. Swiss HIV cohort study. BMJ 1997;315:1194-9.

12 Mocroft A, Vella S, Benfield TL, Chiesi A, Miller V, Gargalianos P, et al. Changing patterns of mortality across Europe in patients infected with HIV-1. EuroSIDA study group. Lancet 1998;352:1725-30.

13 CASCADE collaboration. Survival after introduction of HAART in people with known duration of HIV-1 infection. The CASCADE collaboration. Concerted action on seroconversion to AIDS and death in Europe. Lancet 2000;355:1158-9.

14 Palella FJ Jr, Delaney KM, Moorman AC, Loveless MO, Fuhrer J, Satten $\mathrm{GA}$, et al. Declining morbidity and mortality among patients with advanced human immunodeficiency virus infection. HIV outpatient study investigators. N Engl J Med 1998;338:853-60.

15 Gries JM, Troconiz IF, Verotta D, Jacobson M, Sheiner LB. A pooled analysis of $\mathrm{CD} 4$ response to zidovudine and zalcitabine treatment in patients with AIDS and AIDS-related complex. Clin Pharmacol it 1997;61:70-82. 
16 Ioannidis JP, Cappelleri JC, Lau J, Skolnik PR, Melville B, Chalmers TC, et al. Early or deferred zidovudine therapy in HIV-infected patients without an AIDS-defining illness. Ann Intern Med 1995;122:856-66.

17 Raboud JM, Montaner JS, Rae S, Kahn J, Hammer SM, Katzenstein DA, et al. Meta-analysis of five randomized controlled trials comparing continuation of zidovudine versus switching to didanosine in HIV-infected individuals. Antivir Ther 1997;2:237-47.

18 Kazempour K, Kammerman LA, Farr SS. Survival effects of ZDV, ddI, and ddC in patients with CD $4<$ or $=50$ cells $/ \mathrm{mm}^{3}$.J Acquir Immune Defic Syndr Hum Retrovirol 1995;10(suppl 2):S97-106.

19 HIV Trialists' Collaborative Group. Zidovudine, didanosine, and zalcitabine in the treatment of HIV infection: meta-analyses of the randomised evidence. Lancet 1999;353:2014-25.

20 Staszewski S, Hill AM, Bartlett J, Eron JJ, Katlama C, Johnson J, et al. Reductions in HIV-1 disease progression for zidovudine/lamivudin relative to control treatments: a meta-analysis of controlled trials. AIDS 1997;11:477-83

21 Moher D, Cook DJ, Eastwood S, Olkin I, Rennie D, Stroup DF. Improving the quality of reports of meta-analyses of randomised controlled trials: the QUORUM statement. Quality of reporting meta-analysis. Lancet 1999;354:1896-900.

22 NHS Centre for Reviews and Dissemination. Undertaking systematic reviews of research on effectiveness: CRD guidelines for those carrying out or commissioning reviews. York: NHS Centre for Reviews and Dissemination, University of York, 1996 (CRD report 4).

23 Yusuf S, Peto R, Lewis J, Collins R, Sleight P. Beta blockade during and after myocardial infarction: an overview of the randomized trials. Prog Cardiovasc Dis 1985;27:335-71.

24 Lau J, Ioannidis JP, Schmid CH. Summing up evidence: one answer is no always enough. Lancet 1998;351:123-7.

25 Thompson S. Why sources of heterogeneity in meta-analysis should be investigated. BMJ 1994;309:1351-5.

26 Fischl MA, Richman DD, Grieco MH, Gottlieb MS, Volberding PA, Laskin OL, et al. The efficacy of azidothymidine (AZT) in the treatment of patients with AIDS and AIDS-related complex. A double-blind, placebocontrolled trial. N Engl J Med 1987;317:185-91.

27 Wu AW, Rubin HR, Mathews WC, Brysk LM, Bozzette SA, Hardy WD, et al. Functional status and well-being in a placebo-controlled trial of zidovudine in early symptomatic HIV infection. J Acquir Immune Defic Syndr 1993;6:452-8.

28 Wu AW, Mathews WC, Brysk LT, Atkinson JH, Grant I, Abramson I, et al. Quality of life in a placebo-controlled trial of zidovudine in patients with AIDS and AIDS-related complex. J Acquir Immune Defic Syndr 1990;3:68390.

29 Bucciardini R, Wu AW, Floridia M, Fragola V, Ricciardulli D, Tomino C, et al. Quality of life outcomes of combination zidovudine-didanosinenevirapine and zidovudine-didanosine for antiretroviral-naive advanced HIV-infected patients. AIDS 2000;14:2567-74.

30 Richman DD, Fischl MA, Grieco MH, Gottlieb MS, Volberding PA, Laski $\mathrm{OL}$, et al. The toxicity of azidothymidine (AZT) in the treatment of patients with AIDS and AIDS-related complex. A double-blind, placebocontrolled trial. N Engl J Med 1987;317:192-7.

31 Lane HC, Falloon J, Walker RE, Deyton L, Kovacs JA, Masur H, et al Zidovudine in patients with human immunodeficiency virus (HIV) infection and Kaposi sarcoma. A phase II randomized, placebo-controlled trial. Ann Intern Med 1989;111:41-50.

32 Volberding PA, Lagakos SW, Koch MA, Pettinelli C, Myers MW, Booth DK, et al. Zidovudine in asymptomatic human immunodeficiency virus infection. A controlled trial in persons with fewer than $500 \mathrm{CD} 4$-positive cells per cubic millimeter. The AIDS Clinical Trials Group of the National Institute of Allergy and Infectious Diseases. N Engl J Med 1990;322:941-9.

33 Volberding PA, Lagakos SW, Grimes JM, Stein DS, Rooney J, Meng TC, et al. A comparison of immediate with deferred zidovudine therapy for asymptomatic HIV-infected adults with CD4 cell counts of 500 or more per cubic millimeter. AIDS clinical trials group. $N$ Engl J Med 1995;333:401-7.

34 Fischl MA, Richman DD, Hansen N, Collier AC, Carey JT, Para MF, et al. The safety and efficacy of zidovudine (AZT) in the treatment of subjects with mildly symptomatic human immunodeficiency virus type 1 (HIV) infection. A double-blind, placebo-controlled trial. The AIDS Clinical Trials Group. Ann Intern Med 1990;112:727-37.

35 Gill S, Tang A, Cordery M, Spacey B, Kelly G, Bateman NT, et al. The effects of twice and four times daily zidovudine on p24 antigenaemia in CDC stage II/III patients. Genitourin Med 1991;67:15-7.

36 Merigan TC, Amato DA, Balsley J, Power M, Price WA, Benoit S, et al. Pla cebo controlled trial to evaluate zidovudine in treatment of human immunodeficiency virus infection in asymptomatic patients with haemophilia. NHF-ACTG 036 study group. Blood 1991;78:900-6.

37 Hamilton JD, Hartigan PM, Simberkoff MS, Day PL, Diamond GR, Dickinson GM, et al. A controlled trial of early versus late treatment with zidovudine in symptomatic human immunodeficiency virus infection. Results of the veterans affairs cooperative study. N Engl J Med 1992;326:437-43.

38 O'Brien WA, Hartigan PM, Martin D, Esinhart J, Hill A, Benoit S, et al. Changes in plasma HIV-1 RNA and CD4+ lymphocyte counts and the risk of progression to AIDS. Veterans affairs cooperative study group on AIDS. N Engl J Med 1996;334:426-31.

39 Cooper DA, Gatell JM, Kroon S, Clumeck N, Millard J, Goebel FD, et al. Zidovudine in persons with asymptomatic HIV infection and CD4+ cell counts greater than 400 per cubic millimeter. The European-Australian collaborative group. N Engl J Med 1993;329:297-303.

4 Davey RTJ, Dewar RL, Reed GF, Vasudevachari MB, Polis MA, Kovacs JA et al. Plasma viremia as a sensitive indicator of the antiretroviral activity of L-697,661. Proc Natl Acad Sci U S A 1993;90:5608-12.

41 Koot M, Schellekens PT, Mulder JW, Lange JMA, Roos MTL, Coutinho $\mathrm{RA}$, et al. Viral phenotype and $\mathrm{T}$ cell reactivity in human immunodeficiency virus type 1-infected asymptomatic men treated with zidovudine. J Infect Dis 1993;168:733-6.

42 Concorde Coordinating Committee. Concorde: MRC/ANRS randomised double-blind controlled trial of immediate and deferred zidovudine in symptom-free HIV infection. Lancet 1994;343:871-81.

43 Mannucci PM, Gringeri A, Savidge G, Gatenby P, Laurian Y, Pabinger-Fasching I, et al. Randomized double-blind, placebo-controlled trial of twice-daily zidovudine in asymptomatic haemophiliacs infected with the human immunodeficiency virus type 1 . European-Australian Haemophilia Collaborative Study Group. Br J Haematol 1994;86:174-9.

44 Mulder JW, Cooper DA, Mathiesen L, Sandstrom E, Clumeck N, Gatel JM, et al. Zidovudine twice daily in asymptomatic subjects with HIV infection and a high risk of progression to AIDS: a randomized, double-blind placebo-controlled study. The European-Australian Collaborative Group (study 017). AIDS 1994;8:313-21.

45 Kinloch-de Loes S, Hirschel BJ, Hoen B, Cooper DA, Tindall B, Carr A, et al. A controlled trial of zidovudine in primary human immunodeficiency virus infection. N Engl J Med 1995;333:408-13.

46 Dolin R, Amato DA, Fischl MA, Pettinelli C, Beltangady M, Liou SH, et al. Zidovudine compared with didanosine in patients with advanced HIV type 1 infection and little or no previous experience with zidovudine AIDS Clinical Trials Group. Arch Intern Med 1995;155:961-74.

47 Bozzette SA, Kanouse DE, Berry S, Duan N. Health status and function with zidovudine or zalcitabine as initial therapy for AIDS. A randomized controlled trial. Roche 3300/ACTG 114 Study Group. JAMA 1995;273:295-301.

48 Nielsen C, Bruun L, Mathiesen LR, Pedersen C, Gerstoft J. Developmen of resistance to zidovudine (ZDV) and didanosine (ddI) in HIV from patients in $\mathrm{ZDV}$, ddI and alternating $\mathrm{ZDV} / \mathrm{ddI}$ therapy. AIDS $1996 ; 10 \cdot 625-33$

49 Floridia M, Vella S, Seeber AC, Tomino C, Fragola V, Weimer LE, et al. A randomized trial (ISS 902) of didanosine versus zidovudine in previously untreated patients with mildly symptomatic human immunodeficienc virus infection.J Infect Dis 1997;175:255-64.

50 Niu MT, Bethel J, Holodniy M, Standiford HC, Schnittman SM. Zidovudine treatment in patients with primary (acute) human immunodeficiency virus type 1 infection: a randomized, double-blind, placebo-controlled trial. Division of AIDS treatment research initiative 002 study group J Infect Dis 1998;178:80-91.

51 Evers S, Grotemeyer KH, Reichelt D, Luttmann S, Husstedt IW. Impact of antiretroviral treatment on AIDS dementia: a longitudinal prospective event-related potential study. I Acquir Immune Defic Syndr Hum Retrovirol 1998;17:143-8.

52 Kaulen P, Pham DT, Baranowski E, Wollensak J. Cytomegalovirus retinitis under combination therapy with zidovudine and dideoxycytidine in advanced human immunodeficiency virus infection. Ger J Ophthalmol 1993;2:412-5.

53 Yarchoan R, Lietzau JA, Nguyen BY, Brawley OW, Pluda JM, Saville MW, et al. A randomized pilot study of alternating or simultaneous zidovudine and didanosine therapy in patients with symptomatic human immunodeficiency virus infection. J Infect Dis 1994;169:9-17.

54 Kojima E, Shirasaka T, Anderson BD, Chokekijchai S, Steinberg SM, Broder S, et al. Human immunodeficiency virus type 1 (HIV-1) viremia changes and development of drug-related mutations in patients with symptomatic HIV-1 infection receiving alternating or simultaneous zidovudine and didanosine therapy.J Infect Dis 1995:171:1152-8.

55 Eron JJ, Benoit SL, Jemsek J, MacArthur RD, Santana J, Quinn JB, et al. Treatment with lamivudine, zidovudine, or both in HIV-positive patients with 200 to $500 \mathrm{CD} 4+$ cells per cubic millimeter. North American HIV working party. N Engl J Med 1995;333:1662-9.

56 Vella S, Lazzarin A, Carosi G, Sinicco A, Armignacco O, Angarano G, et al. A randomized controlled trial of a protease inhibitor (saquinavir) in combination with zidovudine in previously untreated patients with advanced HIV infection. Antivir Ther 1996;1:129-40.

57 Hammer SM, Katzenstein DA, Hughes MD, Gundacker H, Schooley RT Haubrich RH, et al. A trial comparing nucleoside monotherapy with combination therapy in HIV-infected adults with CD4 cell counts from 200 to 500 per cubic millimeter. AIDS clinical trials group study 175 study team. N Engl J Med 1996;335:1081-90.

58 Delta Coordinating Committee. Delta: a randomised double-blind controlled trial comparing combinations of zidovudine plus didanosine or zalcitabine with zidovudine alone in HIV-infected individuals. Lance 1996;348:283-91

59 Delta Coordinating Committee and Delta Virology Committee. HIV-1 RNA response to antiretroviral treatment in 1280 participants in the Delta trial: an extended virology study. AIDS 1999;13:57-65.

60 Katlama C, Ingrand D, Loveday C, Clumeck N, Mallolas J, Staszewski S, et al. Safety and efficacy of lamivudine-zidovudine combination therapy in antiretroviral-naive patients. A randomized controlled comparison with zidovudine monotherapy. Lamivudine European HIV Working Group. JAMA 1996;276:118-25.

61 Schooley RT, Ramirez-Ronda C, Lange JM, Cooper DA, Lavelle J, Lefkowitz, et al. Virologic and immunologic benefits of initial combination therapy with zidovudine and zalcitabine or didanosine compared with zidovudine monotherapy. Wellcome Resistance Study Collaborative Group. J Infect Dis 1996;173:1354-66.

62 Moyle GJ, Bouza E, Antunes F, Smith D, Harris D, Warburg M, et al. Zidovudine monotherapy versus zidovudine plus zalcitabine combination therapy in HIV-positive persons with CD4 cell counts 300-500 cells $/ \mathrm{mm}^{3}$ : a double-blind controlled trial. The M50003 study group coordinating and writing committee. Antivir Ther 1997;2:229-36.

63 Fisher M. Nucleoside combinations for antiretroviral therapy: efficacy of stavudine in combination with either didanosine or lamivudine. AIDS 1998;12(suppl 3):9-16. 
64 Foudraine NA, de Jong JJ, Jan Weverling GA, van Benthem BH, Maas J, Keet IP, et al. An open randomized controlled trial of zidovudine plus lamivudine versus stavudine plus lamivudine. AIDS 1998;12:1513-9.

65 Izopet J, Sailler L, Sandres K, Pasquier C, Bonnet E, Aquilina C, et al. Intermittent selection pressure with zidovudine plus zalcitabine treatment reduces the emergence in vivo of zidovudine resistance HIV mutations. J Med Virol 1999;57:163-8.

66 Kuritzkes DR, Marschner IC, Johnson VA, Bassett R, Eron JJ, Fischl MA, et al. Lamivudine in combination with zidovudine, stavudine, or didanosine in patients with HIV-1 infection. A randomized, double-blind, placebo-controlled trial. National Institute of Allergy and Infectious Diseases AIDS clinical trials group protocol 306 investigators.AIDS 1999;13:685-94.

67 Molina JM, Chene G, Ferchal F, Journot V, Pellegrin I, Sombardier MN, et al. The ALBI trial: a randomized controlled trial comparing stavudine plus didanosine with zidovudine plus lamivudine and a regimen alternating both combinations in previously untreated patients infected with human immunodeficiency virus. J Infect Dis 1999;180:351-8.

68 Montaner JS, Reiss P, Cooper D, Vella S, Harris M, Conway B, et al. A randomized, double-blind trial comparing combinations of nevirapine, didanosine, and zidovudine for HIV-infected patients: the INCAS trial. JAMA 1998;279:930-7.

69 Floridia M, Bucciardini R, Ricciardulli D, Fragola V, Pirillo MF, Weimer $\mathrm{LE}$, et al. A randomized, double-blind trial on the use of a triple combination including nevirapine, a nonnucleoside reverse transcriptase HIV inhibitor, in antiretroviral-naive patients with advanced disease. J Acquir Immune Defic Syndr Hum Retrovirol 1999;20:11-9.

70 Friedland GH, Pollard R, Griffith BP, Hughes M, Morse G, Bassett R, et al Efficacy and safety of delavirdine mesylate with zidovudine and didanosine compared with two-drug combinations of these agents in persons ine compared with two-drug combinations of these agents in persons
with HIV disease with CD4 counts of 100 to 500 cells $/ \mathrm{mm}^{3}$ (ACTG 261). with HIV disease with CD4 counts of 100 to
JAcquir Immune Defic Syndr 1999;21:281-92.

71 Revicki DA, Moyle G, Stellbrink H-J, Barker C, for the PISCES (SV14604) Study Group. Quality of life outcomes of combination zalcitabinezidovudine, saquinavir-zidovudine, and saquinavir-zalcitabine-zidovudine therapy for HIV-infected adults with CD4 counts between 50 and 350 per cubic millimeter. PISCES (SV14604) study group. AIDS 1999;13:851-8.

72 Gatell J, Lange J, Gartland M, and the AVANTI Study Group. AVANTI 1: randomized, double-blind trial to evaluate the efficacy and safety of zido-
vudine plus lamivudine versus zidovudine plus lamivudine plus loviride in HIV-infected antiretroviral-naive patients. Antivir Ther 1999;4:79-86.

73 Staszewski S, Morales-Ramirez J, Tashima KT, Rachlis A, Skiest D, Stanford J, et al. Efavirenz plus zidovudine and lamivudine, efavirenz plus indinavir, and indinavir plus zidovudine and lamivudine in the treatment of HIV-1 infection in adults. Study 006 team. $N$ Engl J Med 1999:341:1865-73

74 Cohen Stuart JWT, Schuurman R, Burger DM, Koopmans PP, Sprenger HG, Juttmann JR, et al. Randomized trial comparing saquinavir soft gelatin capsules versus indinavir as part of triple therapy (CHEESE study). AIDS 1999;13:F53-58.

75 Garcia F, Romeu J, Grau I, Sambeat MA, Dalmau D, Knobel H, et al. A randomized study comparing triple versus double antiretroviral therapy or no treatment in HIV-1 infected patients in very early stage disease: the Spanish Earth-1 study. AIDS 1999;13:2377-88.
76 Haubrich R, Thompson M, Schooley R, Lang W, Stein A, Sereni D, et al. A phase II safety and efficacy study of amprenavir in combination with zidovudine and lamivudine in HIV-infected patients with limited antiretroviral experience. Amprenavir PROAB 2002 study team.AIDS 1999:13:2411-20.

77 Quattro Steering Committee. A randomized trial comparing regimens of four reverse transcriptase inhibitors given together or cyclically in HIV-1 infection - the Quattro trial. AIDS 1999;13:2209-17.

78 Kirk O, Katzenstein TL, Gerstoft J, Mathiesen L, Nielsen H, Pedersen C, et al. Combination therapy containing ritonavir plus saquinavir has superior short-term antiretroviral efficacy: a randomized trial. AIDS 1999;13:F9-16.

79 Lewi DS, Suleiman JM, Uip DE, Pedro RJ, Souza RA, Suleiman GS, et al. Randomized, double-blind trial comparing indinavir alone, zidovudine alone and indinavir plus zidovudine in antiretroviral therapy-naive HIVinfected individuals with CD4 cell counts between 50 and $250 / \mathrm{mm}^{3}$. Rev Inst Med Trop Sao Paulo 2000;42:27-36.

80 Ruxrungtham K, Kroon ED, Ungsedhapand C, Teeratakulpisarn S, Ubolyam S, Buranapraditkun S, et al. A randomized, dose-finding study with didanosine plus stavudine versus didanosine alone in antiviral-naive, HIV-infected Thai patients. AIDS 2000;14:1375-82.

81 Goodgame JC, Pottage JC Jr, Jablonowski H, Hardy WD, Stein A, Fisch $\mathrm{M}$, et al. Amprenavir in combination with lamivudine and zidovudine versus lamivudine and zidovudine alone in HIV-1-infected antiretroviralnaive adults. Antivir Ther 2000;5:215-25

82 Opravil M, Cone RW, Fischer M, Vernazza PL, Bassetti S, Lorenzi P, et al. Effects of early antiretroviral treatment on HIV-1 RNA in blood and lymphoid tissue: a randomized trial of double versus triple therapy. Swiss HIV cohort study. J Acquir Immune Defic Syndr 2000;23:17-25.

83 Maguire M, Gartland M, Moore S, Hill A, Tisdale M, Harrigan R, et al. Absence of zidovudine resistance in antiretroviral-naive patient following zidovudine/lamivudine/protease inhibitor combination therapy: virological evaluation of the AVANTI 1 and AVANTI 3 studies. AIDS 2000;14:1195-201.

84 The AVANTI study group. AVANTI 2. Randomized, double-blind trial to evaluate the efficacy and safety of zidovudine plus lamivudine versus zidovudine plus lamivudine plus indinavir in HIV-infected antiretroviral naive patients. AIDS 2000;14:367-74.

85 Conway B. Initial therapy with protease inhibitor-sparing regimens: evaluation of nevirapine and delavirdine. Clin Infect Dis 2000;30(suppl 2):130-4.

86 Stellbrink H-J, Hawkins DA, Clumeck N, Cooper DA, Myers R, Delfraissy JF, et al. Randomised, multicentre phase III study of saquinavir plus zidovudine plus zalcitabine in previously untreated or minimally pretreated HIV-infected patients. Clin Drug Invest 2000;20:295-307.

87 Clarke MJ, Stewart LA. Obtaining data from randomised controlled trials: how much do we need for reliable and informative meta-analyses? In: Chalmers I, Altman DG, eds. Systematic reviews. London: BMJ Publishing, 1995:37-47.

(Accepted 7 November 2001) 